\title{
FABRICATION AND STUDY OF SLIDING WEAR BEHAVIOUR OF ALUMINUM (AA5083) WITH FLY ASH COMPOSITE MATERIAL
}

\begin{tabular}{|c|c|}
\hline Ranjeet Kumar Singh $^{1}$ & Pradeep Kumar Singh $^{2}$;Swati Gangwar $^{\mathbf{3}}$ \\
Department Of Mechanical & Department of Mechanical Engineering, MMMUT, \\
MMMUT, Gorakhpur U.P. 273001 & Gorakhpur U.P. 273001 \\
Email:ranjeet355@gmail.com & \\
\hline
\end{tabular}

\section{ABSTRACT}

The advancement of metal matrix composites (MMCs) is of impressive interest in industrial applications for lighter materials with more specific strength, heat resistance and stiffness. Aluminum-matrix composites (AMCs) reinforced with discontinuous or particle reinforcements are very attractive because they give the best combination of strength, ductility and toughness and they can be processed by traditional process such as rolling, extrusion ,forging, and as a final process, machining. These theses provide sliding wear behavior of composites. Here composite material is fabricated by AA 5083 with fly ash $(0 \%, 4 \%, 8 \%)$. Aim of these theses is produce low cost composite. Fly ash is one of the solid wastes, its produce by thermal power station in large quantity. . At the end, optimize the wear parameter by using Taguchi method with the use of $L_{9}$ orthogonal array.

Key word; fly-ash, metal matrix composite, aluminum, stir casting

\section{INTRODUCTION}

Conventional monolithic materials have limitation good combination of strength, stiffness, toughness; ductility etc so composite material is good choice to short out these problem. Composites materials have high strength to weight ratio and high stiffness. Now days demand of composite material increase compare to conventional monolithic materials. Composite material uses in aircraft, aerospace, automotive industry and home-made application etc. It is possible to developed new composite material with improve mechanical and physical property by study fundamental nature of material and understanding their structure property relationship.

Metal matrix composites have good mechanical property such as tensile strength, impact strength, bending strength, hardness etc, MMCs also improve specific modulus, wear resistance damping capacity, corrosion resistance, stiffness etc. Today, research interest produce MMCs at low cost, low density with improve mechanical and physical property. So use of waste particle use as reinforced increases. Fly ash is one of solid waste which produce by combustion of coal in power plant.fly ash also have low density and inexpensive reinforced particle. Fly ash in aluminum alloy reduced the cost of aluminum product. Today; 1600 engineering material available in market, more than 200 are composites, show importance of composite material as engineering materials [1].

\section{MATRIX MATERIAL}

In the present work, Aluminum alloy (AA 5083) is chosen as a matrix material. It finds many applications such as shipbuilding, rail cars, vehicle bodies, pressure vessel, welded structure, drilling rigs. AA 5083 is excellent ductile and thermal conductivity material. Chemical compositions are AA 5083 given below table. 


\section{(2) \\ ELK \\ Asia Pacific Journals}

Table 1 Chemical composition of AA 5083 alloy [1]

\begin{tabular}{|l|l|l|}
\hline S/N & $\begin{array}{l}\text { CHEMICAL } \\
\text { ELEMENT }\end{array}$ & \% (WEIGHT \%) \\
\hline 1. & Aluminum & Balance \\
\hline 2. & Magnesium & 4 to 4.9 \\
\hline 3. & Iron & $0.40 \mathrm{max}$ \\
\hline 4. & Silicon & 0.0 to 0.4 \\
\hline 5. & Zinc & 0.0 to 0.10 \\
\hline 6. & Titanium & 0.05 to 0.25 \\
\hline 7. & Other & 0.05 to 0.50 \\
\hline
\end{tabular}

AA5083 alloy know as also Mg-Al alloy. Density of aluminum alloy is $2.66 \mathrm{~g} / \mathrm{cm}^{3}$. This alloy withstand at low temperature without loss of property. Above $65^{\circ} \mathrm{C}$ its lose their property.

\section{REINFORCEMENT MATERIAL}

Fly ash produces by combustion of coal in thermal power station (NTPC BADARPUR, DELHI) use as reinforce material. Chemical composition of fly ash is finding out by EDAX. Low cost and low density fly ash produce light weight and low cost composites. Fly ash contains physical property such as low density, high electrical resistivity and low thermal conductivity. In power thermal station, fly ash come out with flue gas and collected through electro-static precipitator.fly ash also known as ESP ash or dry ash. Size of fly ash is 0 to 100 micron. Thermal power station is also produce bottom ash and pond ash/mound ash. Pond ash is mixture of fly ash and bottom ash. Density of fly ash is $2.17 \mathrm{~g} / \mathrm{cm}^{3}$.

\section{FABRICATION METHOD}

The aluminum alloy (AA 5083) based metal matrix composites were designed as per given table (Table 2 ), amounting to $100 \%$ by weights and prepared using Stir casting technique. Stir casting is a liquid state fabrication technique; in which dispersed phase Parameters affect the properties of material by erosion wear, like weight loss, decreased efficiency of component, decreased life of component etc, so the different parameters which effect on sliding wear
ELK Asia Pacific Journals - Special Issue

ISBN: 978-81-930411-5-4
(Fly ash) is mixed with AA5083 alloy (melting temperature of $750^{\circ} \mathrm{C}$ achieved using muffle furnace and graphite crucibles) by manual stirring for 2-3 minute. The mixture is then poured into a permanent mold and allows cooling to room temperature. Thereafter, specimens were cut as per standard size for characterizing physical, mechanical and sliding wear.

Table 2 Design of fabricated composite (fly ash particle with AA 5083)

\begin{tabular}{|l|l|l|}
\hline SET NO & AA 5083 (wt \%) & FLY ASH (wt \%) \\
\hline SET 1 & 100 & 0 \\
\hline SET 2 & 96 & 4 \\
\hline SET 3 & 92 & 8 \\
\hline
\end{tabular}

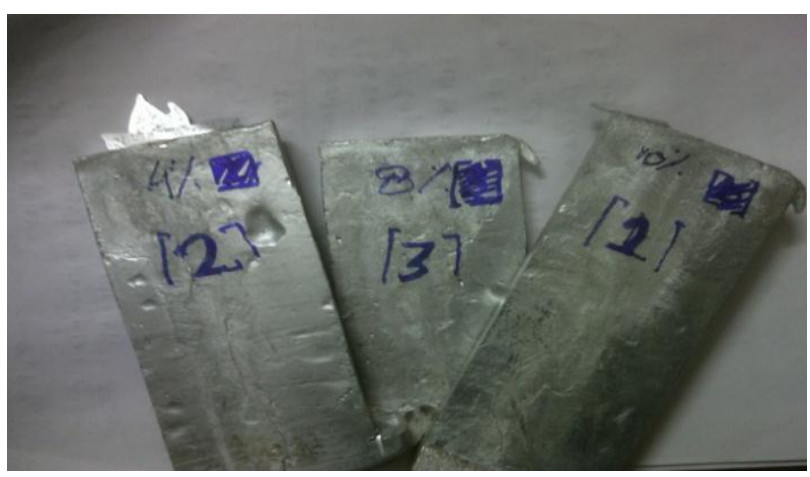

Figure 1 fabricate metal matrix composite plate

\section{SLIDING WEAR CHARACTERISTIC OF COMPOSITE}

Sliding wear is defined as a progressive loss of material occurs from a solid surface owing to a mechanical interaction between the surfaces. Materials that exhibit high wear resistance can increase machinery efficiency by maintaining design tolerance longer than unreinforced materials. For example alumina -reinforced aluminum used as automotive engine pistons results in increased power output together with longer component life. like sliding velocity and load on composites are discussed. 


\section{ELK}

\section{Asia Pacific Journals}

\section{INFLUENCE OF VELOCITY ON SLIDING WEAR RATE}

In the material the sliding wear should be occurred as minimum as possible because if it will high then the life and efficiency of the material will decreases, so from the research it found that sliding wear reduced when velocity decrease.

Table 3 sliding wear rate at different velocity and different filler content (load $15 \mathrm{~N}$ and time $16 \mathrm{~min}$ )

\begin{tabular}{|l|l|l|l|}
\hline $\begin{array}{l}\text { Sliding } \\
\text { velocity } \\
\text { (m/sec) }\end{array}$ & $\mathbf{1 . 0 4 7}$ & $\mathbf{2 . 0 9 4}$ & $\mathbf{3 . 1 4 0}$ \\
\hline $\begin{array}{l}\text { Sliding } \\
\text { wear } \\
\text { rate at } \\
\text { 0\% }\end{array}$ & $100 \times 10^{-11}$ & $\begin{array}{l}474.96 \times 10^{-} \\
11\end{array}$ & $\begin{array}{l}816.72 \times 10^{-} \\
11\end{array}$ \\
\hline $\begin{array}{l}\text { Sliding } \\
\text { wear } \\
\text { rate at } \\
\mathbf{4 \%}\end{array}$ & $75.658 \times 10^{-}$ & $226.95 \times 10^{-}$ & $269.96 \times 10^{-}$ \\
\hline $\begin{array}{l}\text { Sliding } \\
\text { wear } \\
\text { rate at } \\
\mathbf{8 \%}\end{array}$ & $51.04 \times 10^{-11}$ & $140.34 \times 10^{-}$ & $\begin{array}{c}272.99 \times 10^{-} \\
11\end{array}$ \\
\hline
\end{tabular}

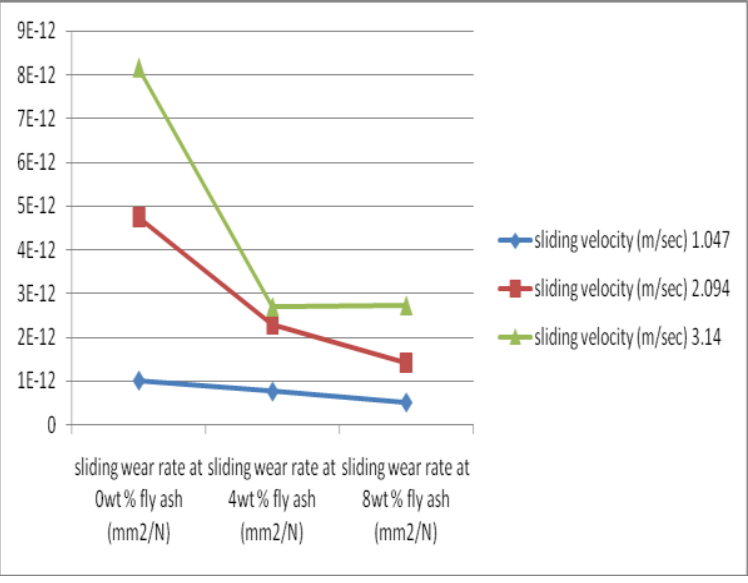

Figure 2 sliding wear load at different velocity ( load $15 \mathrm{~N}$ and time $16 \mathrm{~min}$ )
ELK Asia Pacific Journals - Special Issue

ISBN: 978-81-930411-5-4

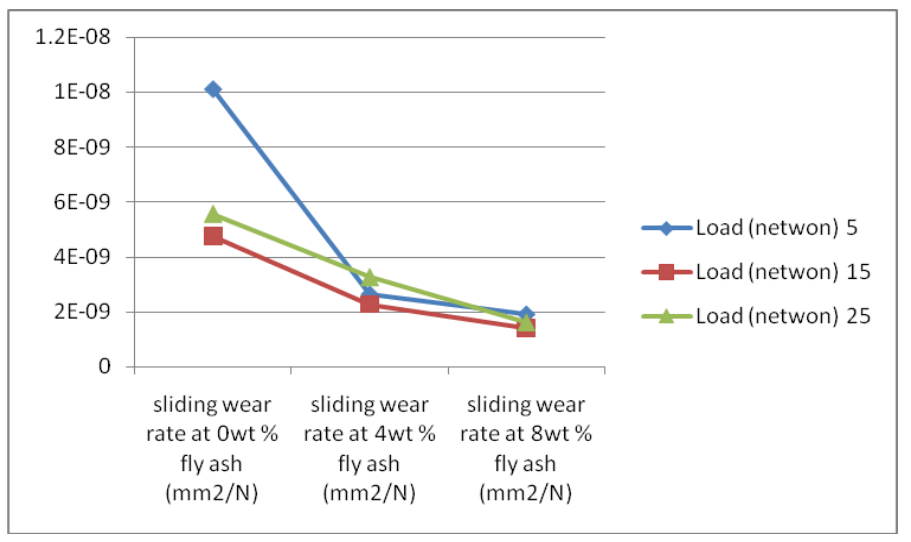

Figure 3 sliding wear load at different load ( velocity 2.094 and time $16 \mathrm{~min}$ )

From above table, sliding wear rate is minimum when sliding velocity $1.047 \mathrm{~m} / \mathrm{sec}$, filler content $8 \%$, load $15 \mathrm{~N}$ and time $960 \mathrm{sec}$.

\section{INFLUENCE OF LOAD ON SLIDING WEAR RATE}

Table4 sliding wear rate at different load and different filler content (velocity $2.094 \mathrm{~m} / \mathrm{sec}$ and time $16 \mathrm{~min})$

\begin{tabular}{|l|l|l|l|}
\hline & $\mathbf{5}$ & $\mathbf{1 5}$ & $\mathbf{2 5}$ \\
\hline $\begin{array}{l}\text { Sliding } \\
\text { wear } \\
\text { rate at } \\
\text { 0\% }\end{array}$ & $1012.5 \times 10^{-}$ & $\begin{array}{l}474.96 \times 10^{-} \\
11\end{array}$ & $\begin{array}{l}555.01 \times 10^{-} \\
11\end{array}$ \\
\hline $\begin{array}{l}\text { Sliding } \\
\text { wear } \\
\text { rate at } \\
\mathbf{4 \%}\end{array}$ & $264.8 \times 10^{-11}$ & $226.95 \times 10^{-}$ & $325.32 \times 10^{-}$ \\
& & 11 & 11 \\
\hline $\begin{array}{l}\text { Sliding } \\
\text { wear } \\
\text { rate at } \\
\mathbf{8 \%}\end{array}$ & $191.4 \times 10^{-11}$ & $140.34 \times 10^{-}$ & $160.77 \times 10^{-}$ \\
\hline
\end{tabular}

For above table sliding wear rate decrease up to $15 \mathrm{~N}$ and after that it is increase. Sliding wear rate is minimum at $15 \mathrm{~N}$ load and $8 \%$ filler material (velocity is $2.094 \mathrm{~m} / \mathrm{sec}$ and time period is $960 \mathrm{sec}$ ). 
ELK

Asia Pacific Journals

OPTIMIZATION OF SLIDING WEAR RATE USING TAGUCHI METHOD

\begin{tabular}{|c|c|c|c|c|c|c|}
\hline $\begin{array}{l}\text { S. } \\
\mathrm{N}\end{array}$ & $\begin{array}{l}\text { Slidin } \\
\mathrm{g} \\
\text { veloci } \\
\text { ty } \\
(\mathrm{m} / \mathrm{se} \\
\text { c) }\end{array}$ & $\begin{array}{l}\text { Filler } \\
\text { conte } \\
\text { nt } \\
(\%)\end{array}$ & $\begin{array}{l}\begin{array}{l}\text { Loa } \\
\text { d }\end{array} \\
(\mathrm{N})\end{array}$ & $\begin{array}{l}\text { Slidin } \\
\text { g wear } \\
\text { rate } \\
\left(\mathrm{mm}^{2} /\right. \\
\mathrm{N})\end{array}$ & $\begin{array}{l}\text { SNR } \\
\text { A }\end{array}$ & $\begin{array}{l}\text { MEA } \\
\mathrm{N}\end{array}$ \\
\hline 1 & 1.047 & 0 & 5 & 75 & $\begin{array}{l}- \\
37.50 \\
12\end{array}$ & 75.00 \\
\hline 2 & 1.047 & 4 & 15 & 25.21 & $\begin{array}{l}- \\
28.03 \\
15\end{array}$ & 25.21 \\
\hline 3 & 1.047 & 8 & 25 & 38.29 & $\begin{array}{l}- \\
31.66 \\
17\end{array}$ & 38.29 \\
\hline 4 & 2.094 & 0 & 15 & 475.01 & $\begin{array}{l}- \\
53.53 \\
41\end{array}$ & $\begin{array}{l}475.0 \\
1\end{array}$ \\
\hline 5 & 2.094 & 4 & 25 & 325.33 & $\begin{array}{l}- \\
50.24 \\
65\end{array}$ & $\begin{array}{l}325.3 \\
3\end{array}$ \\
\hline 6 & 2.094 & 8 & 5 & 459.36 & $\begin{array}{l}- \\
53.24 \\
31\end{array}$ & $\begin{array}{l}459.3 \\
6\end{array}$ \\
\hline 7 & 3.140 & 0 & 25 & 37.51 & $\begin{array}{l}- \\
31.48 \\
29\end{array}$ & 37.51 \\
\hline 8 & 3.140 & 4 & 5 & 113.52 & $\begin{array}{l}- \\
41.10 \\
14\end{array}$ & $\begin{array}{l}113.5 \\
2\end{array}$ \\
\hline 9 & 3.140 & 8 & 15 & 25.52 & $\begin{array}{l}- \\
28.13 \\
76\end{array}$ & 25.52 \\
\hline
\end{tabular}

ELK Asia Pacific Journals - Special Issue

ISBN: 978-81-930411-5-4

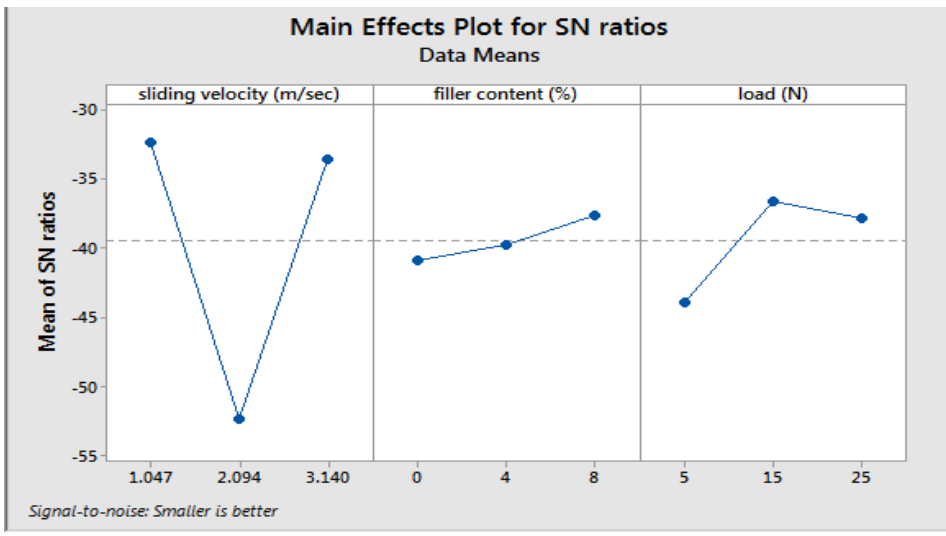

Sliding wear rate is minimum when sliding velocity is $1.047 \mathrm{~m} / \mathrm{sec}$, filler content is $8 \%$ and load apply is $15 \mathrm{~N}$.

\section{RESULT}

Table 3 and Table 4 show sliding wear rate is minimum when load apply $15 \mathrm{~N}$, sliding velocity $1.047 \mathrm{~m} / \mathrm{sec}$ and filler content is $8 \%$. This result is also obtaining Taguchi method with the use of $\mathrm{L}_{9}$ orthogonal array.

\section{SEM ANALYSIS ON SLIDING WEAR}

Before sliding wear

After sliding wear

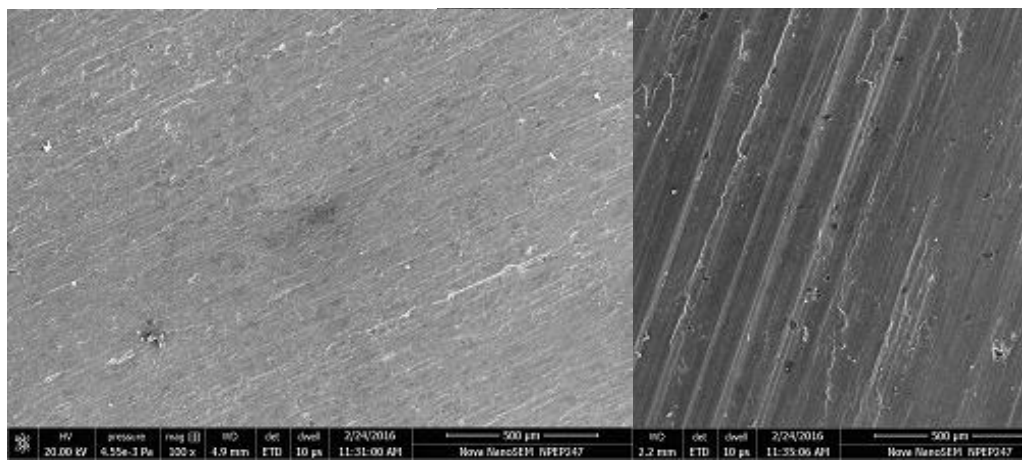

owt $\%$ of fly ash 


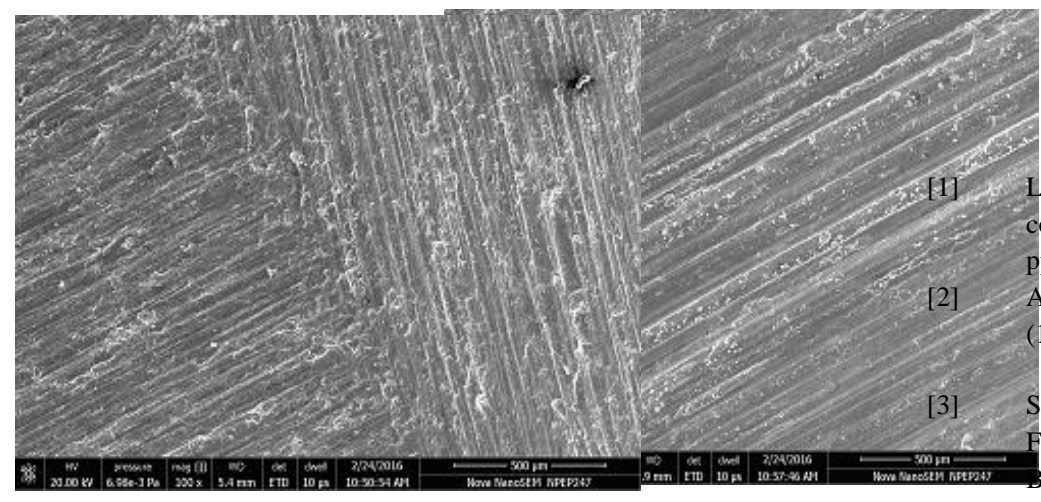

\section{REFERENCES}

L.M. Manocha and A.R. Bunsell, Advances in composite materials, Pergamon Press, Oxford, 1980, pp. 7-21 A. Berghezan, Non-ferrous Materials, Nucleus, 8(5) 1966) 5-11.

[4]

Suresh, A. Mortensen, A. Needleman, undamentals of Metal-Matrix composites, ufferworth-Heinemann, Boston, 1993.

M. Taya, R.J Arsenault, Metal Matrix Composite thermo mechanical behavior, Pergamon press, Oxford, 1989.

[5] A. Sharma, S. Das, Study of age hardening behavior of Al-4.5 wt\% Cu/zircon sand composite in different

$4 w t \%$ of fly ash quenching media-a comparative study, Materials and Design. 30 (2009) 3900-3903

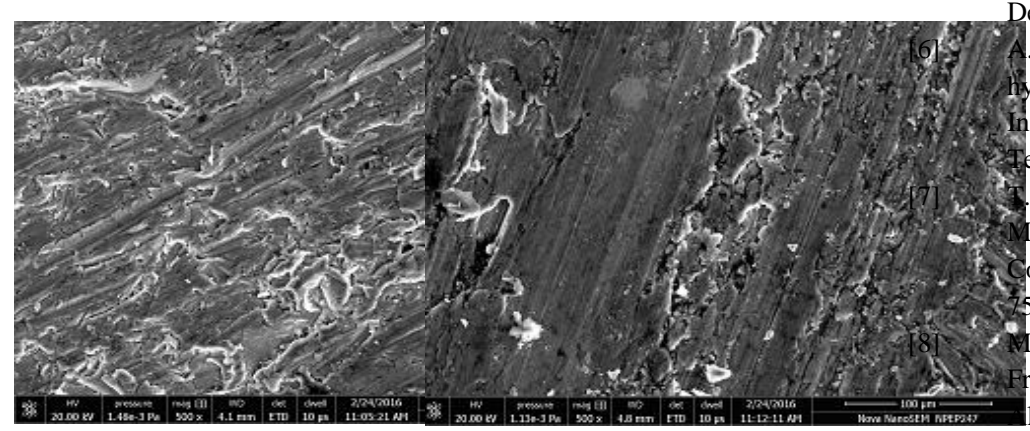

R. Ahamed, P. Asokan, S. Aravindan, EDM of ybrid Al-SiCp-B4Cp and Al-SiCp-Glassp MMCs, nternational Journal of Advanced Manufacturing echnology. 44(5-6) (2009) 520-528.

D. Nixon, J.D. Cawley, Oxidation Inhibition lechanisms in coated Carbon-Carbon

omposites, Journal of American Ceramic Society. (3) (1992) 703-708

I.V. Ravichandran, R.K Prasad, E.S. Dwarakadasa, acture toughness evaluation of aluminium $4 \% \mathrm{Mg}$ $12 \mathrm{O} 3$ liquid-metallurgy particle composite, Journal of Materials Science Letters. 11(8) (1992) 452-456.

$8 w t \%$ of fly ash

[9] V. Kevorkijan, $\mathrm{Mg} \mathrm{AZ} 80 / \mathrm{SiC}$ composite bars fabricated by infiltration of porous ceramic preforms, Metallurgical and Materials Transactions A. 35(2) (2004) 707-715

Figure 4 SEM graph for different wt\% of fly ash before and after sliding wear where load $(15 \mathrm{~N})$ and time (16 min) and sliding velocity $2.094 \mathrm{~m} / \mathrm{sec}$.

\section{CONCLUSIONS}

Stir casting s successfully applied to develop fly ash filled metal matrix composite. The surface topography was successfully investigated by scanning microscopic analysis. This investigation clearly shows the uniform distribution of fly ash in metal matrix composite. Sliding wear reduce with increase of fly ash content in metal matrix composite.
[10] M. Bahraini, E. Schlenther, J. Kriegesmann, T. Graule, J. Kuebler, Influence of atmosphere and carbon contamination on activated pressureless infiltration of alumina-steel Composites Part A: Applied Science and Manufacturing. 41(10) (2010) 1511-1515. 